9. Latuheru, D. (2020). Hasil wawancara Pribadi. SMA Negeri 4 Kairatu.

10. Pesulima, M. (2020). Hasil Wawancara Pribadi. MA Negeri 4 Kairatu.

Received date 21.10.2020

Accepted date 26.11.2020

Published date 25.12.2020

Rostin Talapessy, Pendidikan Sejarah, Program Pascasarjana, Univesitas Negeri Yogyakarta, Setiabudi, Jakarta, Indonesia, 12920

Dyah Kumalasari, Fakultas Ilmu Sosial, Univesitas Negeri Yogyakarta, Setiabudi, Jakarta, Indonesia, 12920

Joniel Hendrik Salouw, Pendidikan Pancasila dan Kewarganegaraan, Program Pascasarjana, Univesitas Negeri Yogyakarta, Setiabudi, Jakarta, Indonesia, 12920

E-mail: laarul892@gmail.com

UDC 37:061.2(477.85)"186/193"

DOI: 10.15587/2519-4984.2020.220482

\title{
CONTENT OF CARE OF STUDENT YOUTH AND CHILDREN IN ACTIVITY OF UKRAINIAN COMMUNITIES AT BUKOVINA (end of XIX - 1914)
}

\section{Zvozdetska}

The article elucidates the activity of Ukrainian communities at Bukovina of the second half of XIX to the end of the Austrian-Hungarian period ("Rusin Talk", "Rusin Rada", "Folk house", "Rusin school”, "Sych", "Myronosistsy", "Women association" and others) in the sphere of social care over children and youth. The special attention is paid to one of great and long-term project - opening and keeping of bursas (dormitories for poor students and natives of rural territories). Causes of the necessity of such institutions are elucidated, the contingent of students, lived in bursas, financing sources, forms of costs involvement for provision and keeping of the institutions, content, forms and directions of learning-upbringing work, realized in bursas, also content of work and a circle of duties of workers of such institutions are described. The article substantiates the importance of bursas functioning for forming national consciousness by involving students in different types of educative work. Form and types of social support and help, such as: cloth and accommodation supply for poor students, opening and keeping of bursas (dormitories); textbook and school accessories supply; monetary "address" payments for poor students, organization of free food for them; help for sick persons; orphan house support are concretized. The activity of communities and separate famous persons in Bukovina in organization of the system of payments for charity projects and creation of special funds is noted. Based on studying archive documents, materials of periodicals, special literature, the review of concrete cases of the charity direction, realized by Ukrainian communities at Bukovina in the studied period, is presented

Keywords: public welfare, public organizations, schools, history of public welfare in Bukovina

Copyright (C) 2020, V. Zvozdetska. This is an open access article under the CC BY license (http://creativecommons.org/licenses/by/4.0).

\section{Introduction}

Changes of main directions and priorities of socio-economic development of modern Ukraine concern functioning of all social institutions.

Economic stratification of the society, appearance of social groups, different by material status, poor financing of social programs in first turn touches children and youth - the weakest and most vulnerable population category.

Social adaptation of children and youth to new economic, political and cultural conditions, formation of life experience that would be a barrier for deviant behavior forms in the growing generation, protection of children's rights and realization of their interests, prevention of abusive treatment of children and their rehabilitation - it is only a small list of questions, adjacent to the problem of childhood and its social protection. It is obvious, that these problems must be solved through the activity of state, pubic organizations, education system at all its levels.

\section{Literary review}

It is important for organizing social protection of children and youth to study the historical experience of this phenomenon, critical understanding of which allows to use best achievements maximally and to integrate 
them in the process of creation of an integral conception of social and socio-pedagogical work at educational institutions.

Ukrainian history knows convincing facts of the constructive role of public organizations in realization of educative and charitable-philanthropic activity, directed on increasing the level of education, culture and general welfare of different population layers, especially children, pupil and student youth. Ukrainian public organizations, acted at the end of XIX - fist third of XX century at Bukovina, such as "Rusin Talk", "Rusin Rada", "Ukrainian folk house", "Ukrainian school", "Women association" and so on are worth attention in this sphere. They defended democratic rights of the Ukrainian nation in the sphere of education; fought for the right for functioning of the native language in all spheres of public life of the region; participated in elaboration of learningmethodical and scientific bases of education of children and adults; realized the comprehensive cultural-educative activity; initiated and realized charitable and philanthropic actions.

The phenomenon of multi-vector activity of Ukrainian public organizations of Bukovina of the studied period is elucidated in scientific studies on regional history, especially by O. Gnatchuk, who studied the activity of Ukrainian women organizations of Bukovina [1], O. Dobrzhansky, who realized the profound historical analysis of causes of generation and development of the national movement at Bukovina and proved the role of public organizations in formation of the Ukrainian national idea [2]. As to historical-pedagogical scientific studies, V. Zvozdetska investigated the wide spectrum of activity of Ukrainian communities of the AustrianHungarian and Romanian periods of Bukovina [3], M. Marchuk studies and analyzes the phenomenon of social care at Bukovina, starting from preschool education, finishing by care of adult Bukovina dwellers [4], O. Penishkevych realized a fundamental research, discovering the question of development and formation of education at Bukovina [5], I. Petriuk studied and described formation of the system of secondary education at Bukovina, indicating the additional possibility to study in the second half of a day for students, living in bursas [6], L. Platash [7] and T. Sholina [8] in their works studied and analyzed living and professional ways of famous persons at Bukovina, according to O. Popovych and S. Smal-Stotsky, who occupied high posts and favored opening of bursas, L. Timchuk described the process of generation and formation of the system of adult education at Bukovina and noted participation of bursa students in different educational arrangements [9]. All aforesaid researches concerns the period, covered in the article.

The analysis of the scientific literature testifies that the determining role in formation of the social care tradition at educational institutions in different historical periods was played by public organizations.

\section{Research aim and tasks}

Research aim is to elucidate the content and forms of social care over children and youth, involved in the educational process at different educational institutions of Bukovina for the end of XIX - 1914, realized by Ukrainian communities of the region.

The following tasks were set for attaining the aim:

1. To characterize bursas as a form of social care.

2. To concretize forms and types of social support and care, demonstrating the interconnection between the social care sphere and educational one.

\section{Materials and methods}

The used methods: searching-bibliographic (analysis of bibliographic catalogues and textbooks, search of materials, adjacent to the research problem, setting of the bibliographic research base), historical-retrospective (based of studying archive materials, reconstruction of the integrity of the process by previously unknown details) and comparative-juxtaposing (comparison and juxtaposition of historical-pedagogical events, processes for separating common and different).

\section{Research results and their discussion}

The second half of XIX - 1914 is the period, when the most territory of the modern Chernivtsi region was a part of Austria-Hungary.

Events, caused by constitutional reforms of Austria-Hungary of 60-ies of XIX century became crucial in processes of generation and development of the civic movement in the region. Especially, the Main law of 21 of December of 1867 declared equality of all citizens for law, and the law of 15 of November of 1867, named "On community right", opened possibilities for legal political fight for widening and realization of national right of one or another nation, making them directly dependent on how a certain nation can protect itself and to provide own legal rights.

After adoption of such law, active formation processes of community relations took part at Bukovina, such public organizations as "Rusin Talk", "Rusin Rada", "Folk house", "Rusin school", "Sych", "Myronosistsy", "Women association" and other were found. The content of their activity is characterized by the wide spectrum of directions - cultural-educational, political, scientific-educational, scientific-pedagogical, class (teacher, worker, peasant, youth pupil and student), socio-economic, charitable-philanthropic and so on.

Let's note, that there is almost not observed a "pure" type among the studied communities, their activity programs were not limited by anyone direction. Grouping around political interests or education ideals, by motives of economic profit or protection of financial interests and cultural tastes, the progressive circles of Bukovina set and realized much wider aims and tasks that for that day sounded as the highest purpose of the whole social movement - national self-consciousness of the Ukrainian population, favoring of growth of education and general cultural level of Ukrainians, strengthening of their socio-political status and general welfare increase.

Great scales of the activity of the communities are remarkable in the sphere of social care and support, regulated by their basic documents. Statutes contained distinctly formulated directions of social care over children and youth, manifested in different forms - vindication of rights of children of all classes for education in native 
language, opening of learning and patronage-upbringing institutions of different types and levels, material support and so on.

As it was noted in statutes of the communities, they gave help in different forms. The essential help for getting education by children from poor families and rural natives was opening of bursas. It facilitated the learning process, because there was no necessity to travel to an educational institution or rent an expensive accommodation. Such form of support of all, who wanted to study, originated from the Middle Ages, when dormitories with the same name, bursa, were created near universities in the Western Europe. Bursas were kept partially by costs of universities, partially by ones, gathered by students among rich city dwellers. The word "bursa" originates from Latin, where it meant "cowhide", "skin purse". This purse was fastened to bursa doors for donations, put by rich bourgeois.

Initiators of such institutions at Bukovina in the studied period were Ukrainian communities "Rusin school", "Folk house", "Women association", understanding that an essential obstacle on the way to the normal development of Ukrainian school was inability of the essential part of parents to keep their children-pupils, to provide them with conditions, necessary for study.

Due to common efforts of the communities "Rusin school" and "Folk house" one of firsts bursas, named after the famous regional writer Y. Fedkovych, started to work in 1896 in Chernivtsi. It took place by the support of local authorities - the Seym of Bukovina gave financial help of 200 rinsky [10]. The stimulus for opening this institution was introduction of Ukrainian classes at the Second German gymnasia in Chernivtsi in 18961897. Bursa students, which number in the first year was 20 persons, were not only gymnasia pupils, but also ones of real school and teacher seminary. At this institution they had a possibility to get such services as "an accommodation with accessorizes; healthy food; supervision; help in education and healing; bath; heat; light; laundering" [11]. Bursa dwellers paid for that the quite symbolic sum - 13 kor 42 sot every month, and poor students received financial aid - 200 kor a year [11]. Such financial aid completely covered costs for dwelling at bursa.

Several bursas, both in Chernivtsi and other cities of the region - Vashkivtsi-on-Cheremosh, Vizhnitsia, Kitsman, Seret functioned under patronage of "Rusin school". Their opening was usually resonant and ceremonial, approved by the regional community. For example, according to the newspaper "Bukovina", one of most important events of the year was opening of just two bursas in 1908 in Vizhnitsia - general and orthodox [12]. It must be noted, that bursas, opened in different parts of the region, were usually established on the example of the Chernivtsi bursa, named after Yuriy Fedkovych, became one of most famous at Bukovina, and, as further history demonstrated it, played the important role in the growth of youth consciousness. Just bursa students organized music-declamatory evenings and amatory theatric performances, spending received costs for helping their poor mates, and also gathered costs for own needs. Especially, costs, received from successful amatory theatric performances, were spent by students of the "Bursa, named after Y. Fedkovych in Chernivtsi" for supplying a big library with textbooks, necessary for learning, and different books for free reading.

The community "Rusin school" also intended to open a bursa for girls in 1902, but there were no ones who wish, and it was postponed [10]. But the Ukrainian community didn't leave ideas about the necessity of this institution, understanding that such dormitories not only solve problems with dwelling for rural female students, but also have a great educational potential. Foundation of a bursa for girls, as the newspaper "Kamenyary" stated it, is "... an interest of our society, for our girls-students, a hope of better chance of the Rusin nation, get education not only at schools, but mainly good religious-moral education beyond them" [13].

This task was realized, as primary sources state it, by women communities of Bukovina. It is known, that already at the first year of its activity "Women association" addressed to the city council of Chernivtsi with the request to allocate for free an area at the Monastyrsko suburb (near the modern Starozhynska street) for building a bursa-institute for maids [14]. And such institution was opened already in 1910.

It was possible to enter the bursa only by the competition. At the beginning 25 girls were there. In the next 191145 girls were admitted. In 191367 girls entered the bursa, then 80 more [15]. Bursa management was headed by the teacher Y. Tsukanovych. Also the teacher V. Pavlovych and the priest E. Sermaka cared over the bursa [16].

Let's underline, that the Ukrainian community of Bukovina at the beginning of XX century paid almost greatest attention to opening of bursas in problems of care and support of children and youth. Bursas were second important learning-upbringing institutions after schools by quality and quantity characteristics. "They gave even that school didn't give" - D. Kvitkovsky noted [15].

The "bursa committee" managed the institution. It included from 5 to 12 pupils, depending on material possibilities of the institution and number of pupils. A host, three deans (tutors), inspector were chosen of them. A supervisor, responsible for students' behavior and cleanness, was elected in each room. Pupils organized competitions for the best accommodation rather often. Tutors were responsible for cultural mass work with bursa students: organization of meetings for discussing certain topics that every time changed, concerts, visits to the theater, circus and for individual work with separate students. The post of inspector in bursa was occupied by a person, who knew teaching methods enough. His/her duties included help in home work of bursa students. If a student missed school or didn't understand a "lecture", the inspector repeated it at bursa for all who wish.

Sometimes one of gymnasia professors was employed at bursa for helping pupils in home tasks completion and for supervision of their behavior. He must obligatorily live in the institution, to help inspectors in upbringing of pupils, to assist bursa students in conduction and organization of upbringing arrangements. The influence of educators, inspectors on bursa students was intensified also by one of members of student communities "Union", "Sych", "Chornomore", who unofficially involved pupils to organized arrangements. Libraries functioned at the institutions for self-education of gymnasia 
pupils, development of their creative abilities and talents, and courses of English, sports clubs and theatric groups of imitative amateurs and solo signing were organized at the bursa, named after Yuriy Fedkovych. Pupils' moral consciousness formed at bursas, behavioral skills and habits were mastered, healthy lifestyle bases were generated. As to the last point, physicians worked at most institutions, conducted the explaining work with pupils about the harm of alcohol and nicotine for health, advantage of physical exercises and training, gave free medical help for pupils and free medicaments - for poor ones. Gymnasia communities with the same name functioned at bursas. The periodical "News from the community of orthodox gentry at Bukovina" gives information about the community "Vizhnytsa bursa". The main purpose of its activity was determined as favoring material welfare of the institution and educational and upbringing work among bursa students [17].

The effectiveness of the educative influence of such institutions and their role in the development of national self-consciousness and morality of educators of regional schools at the end of XIX - beginning of $\mathrm{XX}$ century is testified by approving opinions of press. Especially, the newspaper "Bukovina" wrote about the Kitsman bursa's activity: "Kitsman bursa belongs to institutions that must be maintained (understood, support V. Z.) by each Bukovina patriot" [18].

Another practical manifestation of intentions to support the Ukrainian student youth, declared in statutes if the communities, was such types of help as supply with cloth and monetary payments. The analysis of publications of that time periodical and content of archive cases about the activity of regional communities revealed the great amount of concrete facts of such "caring" activity of the communities.

Especially, as the newspaper "Bukovina news" informed, in January of 1895 members of the "Assosiation of Rusin women" presented winter cloth to 31 girls [19]. This activity continued in the next years also. Thus, according to reports of the "Association of Rusin women", it was calculated, that in $1896-1898$ poor girls received winter cloth for $253 \mathrm{zl}$, gathered by volunteer donations, as a present.

The activity of the community "Myronosytsy", which members during 1898 collected $214 \mathrm{zl} .35$ kor for buying winter cloth for 70 poor girls-students of folk schools, was also effective. It was also noted, that such community members as “... Olga Kaluzhnyatska, Emilia Smal-Stotska, Naja, Glinska, Oksana Dobryanska, Povroznik, Andrushko, Gudzinska also actively collected costs [19].

In 190012 active members of the community "Myronosytsy" gathered among rich layers of the Chernivtsi population 1150 kronas for needs of poor schoolchildren for buying «...34 bundas (short sleeves fur coat - V.Z.), 33 pairs of boots, 68 pairs of shoes, 29 trenches and mantles, 68 dresses, 16 plaids». In such a way 150 girls and 67 boys received help. It was informed by the local newspaper "Rusin rada" [20].

Supply of poor pupils with cloth became an ordinary business also for the community "Rusin school", created just for support and satisfaction of needs of Ukrainian schoolchildren [21]. At the same time let's note, that such type of help as monetary payments school fee for poor children, one-time money help, allocation of costs for buying school accessorizes, textbooks and so on is remarkable among the list of charitable actions of this community. Thus, according to the material of the report about the community work, let's cite for example the list of cases of one-time money payments: "School city" of the community of "Orthodox Rusin women" in Chernivtsi - 100 kor, Vashkivtsy real gymnasia -300 kor, one academician for charges in preparatory course for secondary schools - 45 kor, Ukrainian folk schools in Voloskim-Banilov - 150 kor, in Korchivtsy 70 kor, in Chagry - 100 kor, Kuchuriv Velikiy - 50 kor, students of the Chernivtsi Ukrainian gymnasia - one 25 kor, second 40 kor, one student of the state teacher seminary received 40 kor with the duty to return from salary; 1 student of the state teacher seminary - 16 kor., one girl-student of the teacher seminary - 16 kor" [22].

The analogous work was also realized by affiliated branches of "Rusin school". It is known, that the Vizhnytsa affiliated branch allocated from its funds 27 kor 60 sot for keeping one gymnasia student in the local gymnasia [22]. The Zastavny affiliated branch in 1912-13 academic year paid the money help for several poor students, entered the Kitsman gymnasia [13]. The Kimpolung affiliated branch kept one girl of the folk school and allocated 80 kor for this aim. [22]. The Storozhynetska affiliated branch in 1913 allocated help for one student of its school as 50 kor, one pupil of the secondary school -120 kor [22]. The Seret affiliated branch kept in 1912-13 academic year 12 pupils in the Kitsman gymnasia with cost of 1126 kor. At the same time, as was noted in the report about the community work, the affiliated branch constantly cared over poor youth - allocated help for pupils for buying books, fees for studying at school, copybooks and cloth in Sherbivtsi, Vovchintsi, Meretsei - total sum 88 kor 26 sot; and also paid for several poor students of the Seret gymnasia [22].

Essential efforts of the community were directed on pupils supply with school accessorizes, textbooks and fiction. The activity of the community "Ukrainian school" that sent ".. to poor communities school textbooks or own editions and most - orthodox player books" was important in this matter [22]. The community "Ukrainian school" presented to the city affiliated branch of the "Rusin Talk" 100 books of own editions for children at the Nicolas holiday; the section of the community "Ukrainian school" presented to the Vashkivtsy affiliated branch several copies of their editions for the Vashkivtsy real gymnasia. The community initiated the tradition to reward best pupils of primary and secondary schools with books at Saint Nikolas day [22].

The community "City reading hall in Chernivtsi" that "... credited poor pupils with books for school..." favored pupils' supply with literature in Ukrainian [23].

The communities also made essential efforts for helping Ukrainian children, especially ones from poor families, to get full-value education, passing the complete learning course. But it must be understood, that the communities themselves had no enough financial resources for making this activity large-scale. We appeal to concrete cases that, as it is proved by the source base, were numerous, but it was not regular and system coor- 
dinated work. Money payments and supply with cloth were mainly one-time and address. It is clear, because the studied Ukrainian communities were not commercial organizations. Their monetary funds are filled mainly at the expanse of volunteer contributions and donations of citizens. A part of costs came from cultural-educational and entertaining events, conducted by the communities for charity purposes.

At the same time for filling monetary funds for schoolchildren's needs and for supporting pupils from poor families, the communities many times addressed to official power authorities with correspondent requests, wrote petitions to the Bukovina Seym about foundation and filling of school libraries, about help for pupils, support of educational initiatives. Thus, as a result of persistent efforts, the community "Ukrainian school" received in 19135000 kor from the Bukovina Seym for schoolchildren's needs, and 700 kor were received as a fee for the textbook by S. Kaniuk "Didactics" [22]. The part of costs was also allocated by the Regional School Council. But such receipts were not constant and had mainly spontaneous character.

So, striving for organizing and regulating the support of needy schoolchildren, activists of the "Rusin school" and "Rusin talk" initiated foundation of the independent community "School help", which main business was to "... give help to school youth" [11]. The community solved questions of giving different help to poor Ukrainian pupils. Especially, it was noted in its statute that: "The community gives male and female students such help as:

a) credits them with school textbooks and other books, correspondent to their education;

b) gives them free school accessorizes, and also present cloth if their means and funds allow it;

c) gives a correspondent money help to closest relatives of a pupil;

d) provides rural children, visiting local higher schools, with helps and stipends [2].

The first such community was created in 1901 in Chernivtsi [24]. Then "School helps" were founded also in other settlements of the region. According to the "Bukovina orthodox calendar", at the end of 190513 communities of "School help" functioned in the region, and almost such number - 14 communities - remained the day before the First World War [25].

The community usually included local teachers and school administration, representatives of local authorities, head of court, deputies, famous dwellers and other citizens, wanted to support the needy Ukrainian youth [24].

Special "helping funds" were also created by Ukrainian students, pupils of secondary schools, belonged to the communities "Union", "Young Ukraine", "Sych", "Orthodox academy", "Zaporozhe", "Chornomore". Funds, created at the expanse of counting off from member contributions, profits from different entertainment events and donations of rich citizens, were used for giving interest-free loans, one-time helps and so on to members of the communities. At the same time Ukrainian academic youth organizations from time to time convoked general public meetings for combining their efforts and conducting common arrangements as to this business. Especially, 30 of November of 1913 the gen- eral public meeting of the Ukrainian student youth took place at the Ukrainian Folk House in Chernivtsi, approved the idea to create a separate community, named "Academic help", aimed at: "a) to keep a subsidiary fund; b) student kitchen; c) problem of cheap accommodation, building of the National Academic house" [26]. The public meeting elected the Student committee, included two persons from each Chernivtsi Ukrainian academic community: "Union", "Sych", "Orthodox Academy", "Zaporozhe" [26]. Events of the First World War didn't allow to realize students' intentions.

But both pupils of gymnasia and primary schools received help from funds of the "School help". Generally, let's note, that the activity of these communities was long-term and effective. But if take into account sizes of the region, such centers were not numerous. Not only poor schoolchildren, but school as such needed support.

13 of June of 1909 the general meeting of the community "Ukrainian school" accepted the decision about creation of the separate section "School fund" with the task to "find necessary monetary resources for Ukrainian school needs" [27]. Only in a year, 28 of June of 1910 the general meeting of the "Ukrainian school" accepted the work of the section "School fund" [22]. The section included: the Head - physician Evgen Burachinsky, assistant - P. Klim, cashier - N. Kopachuk, secretary - V. Vatsyk, controller - R. Dudych.

The work of the section started from appeals to the regional publicity to donate costs for educational needs. One of main incomes was the so-called national tax of three types:

1) contributions of intellectuals as a duty;

2) contributions of all communities;

3) profits from different folk entertainments amusements, concerts, theatric performances [22]. Money was collected at first by couriers, then - by students.

The national tax was paid one time and by month contributions (from 0.50 to 2 korons). It was important to persuade the Ukrainian population of the region to pay the voluntary tax on the account of the "School fund". But up to 1914 only 80 persons in Chernivtsi manifested desire to pay the "national tax" (it concerned both onetime and regular payments). Names of all people, paid the national tax, are listed in the report about the work of the "Ukrainian school community", printed as a separate brochure, of 22 of March of 1914. Among them are mainly teachers, professors of secondary schools and university, separate officials. Provincial intellectuals demonstrated almost complete inactivity [10].

Essential efforts were directed by the section "School fund" on production and distribution of stamps, copybooks, telegrams and other things with attributes of the "Ukrainian School". The section had profits from "coupons" (checks), given at buying of one or another goods, and a certain share of their sale was assigned for the "School fund" needs. But the work was loweffective, because the readiness to donate of Bykovyna Ukrainians was unessential, and the attitude to education often indifferent or even reluctant.

\section{Conclusions}

1. The patronage-charitable activity of Ukrainian communities in pre-war years was an unalienable compo- 
nent of their cultural-education activity. Opening and keeping of bursas - dormitories for pupils from needy families was especially important for attracting more number of children and youth to education. These places played much more role than a dwelling place, they became centers of education activity for bursa dwellers, then involving them in conducting it in the region.
2. Numerous facts of giving material support for children from needy families, orphans, provision them with dwelling, cloth, school accessorizes, care about education of Ukrainian children and so on is a confirmation of the fact that aims and tasks "to help student youth", declared in statutes, turned out not populist, but were embodied in concrete and real activities.

\section{References}

1. Hnatchuk, O. (2001). Ukrainski zhinochi orhanizatsii na Bukovyni (80-ti roky XIX - 30-ti roky XX st.). Chernivtsi, 20.

2. Dobrzhanskyi, O. (1999). Natsionalnyi rukh ukraintsiv Bukovyny druhoi polovyny XIX - pochatku XX st. Chernivtsi Zoloti lytavry, 574

3. Zvozdetska, V. H. (2012). Osvitno-vykhovna ta prosvitnytska diialnist ukrainskykh hromadskykh orhanizatsii Bukovyny (druha polovyna XIX - 30-ti roky XX st.). Khmelnytskyi, 20.

4. Marchuk, M. V. (2016). Rozvytok suspilnoi opiky ditei ta molodi na Bukovyni (kinets XIX - persha tretyna XX st.). Khmelnytskyi, 20.

5. Penishkevych, O. I. (2002). Rozvytok ukrainskoho shkilnytstva na Bukovyni (XVIII - pochatok XX st.). Chernivtsi: Ruta, 520.

6. Petriuk, I. M. (1998). Stanovlennia ta rozvytok serednoi osvity na Bukovyni v kintsi XVIII - na pochatku XX st. IvanoFrankivsk: Prykarpatskyi un-t im. V. Stefanyka, 18. $105-116$.

7. Platash, L. (2012). Omelian Popovych - bukovynskyi diiach kintsia XIX - pochatku XX stolittia. Vyshcha shkola, 10,

8. Sholina, T. (2005). Rol Stepana Smal-Stotskoho v prosviti ukrainskoho naselennia Bukovyny kintsia XIX - pochatku XX stolittia. Ideia opiky ditei i molodi v istoryko-pedahohichnii nautsi. Ivano-Frankivsk, 212-216.

9. Tymchuk, L. (2005). Orhanizatsiino-pedahohichni zasady ukrainskoi osvity doroslykh na Bukovyni (1869-1940 rr.). Ivano-Frankivsk, 20.

10. Haras, M. (1937). Iliustrovana istoriia tovarystva «Ukrainska shkola»v Chernivtsiakh (1887-1937): pamiatna knyzhechka, vydana z nahody 50-ykh rokovyn isnuvannia tsoho tovarystva. Chernivtsi: Typohrafiia «Ceas», 133.

11. Novynky. Holovni zbory tovarystva «Ruskyi Narodnyi dim»v Chernivtsiakh (1909). Bukovyna, 202, 3.

12. Shcho vazhnoho stalosia u nas v 1908 r.? (1909). Bukovyna, 9, 1-2.

13. Kameniari (1911). Chernivtsi.

14. Iz «Zhinochoi hromady» (1906). Bukovyna, 66, 3.

15. Kvitkovskoho, D., Bryndzana, T., Zhukovskoho, A. (Eds.) (1956). Bukovyna, yii mynule suchasne. Paryzh; Filadelfiia; Detroit: Zelena Bukovyna, 965.

16. Narodnyi holos (1910). Chernivtsi.

17. V spravi zasnuvannia ukrainskoi bursy. Visti z tovarystva pravoslavnoi shliakhty na Bukovyni, 1, 1.

18. Visti (1901). Bukovyna, 4.

19. Bukovynskye vedomosty (1895). Chernivtsi, 8.

20. Ruska Rada (1900). Chernivtsi.

21. Statut tovarystva «Ruska Shkola» v Chernivtsiakh (1800-1900). Chernivtsi: Pechat Choppa, 12.

22. Zvit pro robotu tovarystva «Ukrainska shkola» (26 rokiv) (1914). Chernivtsi, 51.

23. Zahalni zbory tovarystva «Mishchanska chytalnia v Chernivtsiakh» (1909). Bukovyna, 150, 123

24. Bukovyna. Chasopys politychna i naukova dlia narodaruskoho (1903). Chernivtsi, 18.

25. Bukovynskyi pravoslavnyi kalendar na zvychainyi rik 1906 (1905). Chernivtsi: Nakladom lit. tovarystva «Ruska Besida», 112.

26. Nova Bukovyna (1913). 1.

27. Protokol zahalnykh zboriv tovarystva «Ukrainska shkola»13.06.1909 r. (1909). Bukovyna, 138.

Received date 22.10.2020

Accepted date 26.11.2020

Published date 25.12.2020

Valentyna Zvozdetska, PhD, Assistant, Department of Pedagogy and Social Work, Yuriy Fedkovych Chernivtsi National University, M. Kotsiubynskoho, 12, Chernivtsi, Ukraine, 58012

E-mail:v.zvozdetska@chnu.edu.ua 